Nuntius Antiquus, Belo Horizonte, v. 13, n. 1, p. 39-57, 2017

\title{
Fiama Hasse Pais Brandão: escrita poética recriando os clássicos ${ }^{1}$
}

\section{Fiama Hasse Pais Brandão: A Poetic Writing That Recreates the Classics}

\author{
Maria do Céu Fialho \\ Universidade de Coimbra, Coimbra / Portugal \\ mcfialhofluc@gmail.com
}

Resumo: A diversificada formação cultural de Fiama, o multiculturalismo que em si assume e lhe corre no sangue constituem a razão mais forte para que esta procura poética, que é procura da vida e do seu sentido mais profundo, seja imbricada, labiríntica, propícia à recolha reflexiva em si mesma ou no útero-caverna das palavras e do pensamento antiquíssimo, como recolha iniciática. Assim, perseguir na sua obra poética marcas do universo greco-latino leva-nos, inevitavelmente, à verificação de que raras vezes elas se encontram isoladas, autónomas, alheias a associações outras. Fiama põe lado a lado contemporaneidade e Mundo Antigo, geografias diversas, como $O$ Xanto, o Tibre e o Reno, poesia alemã e grega, universo bíblico e universo helénico ou romano.

Palavras-chave: multiculturalismo; cabala; correspondências culturais; Os Clássicos e os Outros.

Abstract: The diversified cultural formation of Fiama, the multiculturalism that she embodies and that runs in her blood are the strongest reasons to make this poetic search. This is the search for life itself, and its deeper

\footnotetext{
${ }^{1}$ Este estudo corresponde a uma versão actualizada e aprofundada do trabalho publicado em Revista Pessoa, v. 2, 2010.
} 
meaning, be it imbricated, labyrinthine, or conducting to a reflexive recollection in itself, or in the uterus-cave of words and ancient thought, as an initiatory collection. Thus, to pursue in her poetic work the marks of the Greco-Latin universe leads us, inevitably, to the fact that they are seldom isolated, autonomous, unrelated to other associations. Fiama puts side by side Contemporaneity and the Ancient World, diversified geographies such as The Xanthus, the Tiber and the Rhine, German and Greek poetry, the biblical universe, and the Hellenic and Roman universes.

Keywords: multiculturalism; kabbalah; cultural correspondences; The Classics and the Others.

Recebido em: 20 de março de 2017.

Aprovação em: 30 de julho de 2017.

Fiama Hasse Pais Brandão, de ascendência judaica por via materna e neta do escritor Raul Brandão, nasceu em Lisboa, no ano de 1938, e vem a falecer em Lisboa, em inícios de 2007. A sua infância foi passada numa quinta em Carcavelos, entre o enquadramento da natureza verdejante e das fainas rurais e a presença próxima do elemento aquático: o rio Tejo. Frequentou o liceu inglês, St. Julian's School, até ingressar na Universidade de Lisboa, no curso de Letras Germânicas, que combinava o ensino das línguas, culturas e literaturas alemã e a inglesa.

Do liceu inglês traria, certamente, uma boa formação no domínio das Línguas Clássicas, a que as aulas de Cultura Clássica, leccionadas pelo sábio e talentoso comunicador doutor Manuel Antunes, terão, certamente, acrescentado o estímulo de fascínio pela Antiguidade Grecoromana, que jamais a abandonará.

Desde cedo igualmente atraída pelas dimensões do hermético e da Cabala, Fiama sente as vozes culturais de múltiplas origens que lhe correm nas veias, que a cercam ou que a escola the mediou. Entre as raízes da cultura judaica, a literatura portuguesa, em particular, Camões, o imaginário anglo-saxónico e antigo, o perpétuo fluir das águas e o ciclo 
incessantemente renovado da Natureza, Fiama busca, insaciável, a síntese, a unidade, a paz. A Cabala, como instrumento de leitura de um mundo de conversões e de equivalências, torna-se, assim, para ela, fundamental.

Não se espere, pois, encontrar em Fiama uma escrita fácil - em contrapartida, encontrar-se-á uma escrita quase mágica, que envolve e arrebata o leitor, preso pelo ritmo, pela imagem, pelo som, e por essa teia de elementos de correspondências a decifrar.

Como aluna da Faculdade de Letras, torna-se uma das fundadoras do Grupo de Teatro das Letras. E como parece inevitável esperar deste espírito ímpar, estamos perante uma mulher de actividade poligráfica: Fiama dedicou-se à poesia, compôs obras dramáticas (recebeu o prémio Revelação de Teatro com a peça Chapéus de chuva, 1961), escreveu ensaios (é profunda conhecedora de Camões), dedicou-se à tradução (entre outras, de obras de John Hoyer Updike, Bertolt Brecht, Antonin Artaud, Novalis/ Georg Philipp Friedrich von Hardenberg, Anton Tchekov) e, na última década da sua vida, à prosa ficcional (Sob o olhar de Medeia, 1998).

Estreou como autora com Em cada pedra um voo imóvel (1957). No entanto, vem a ganhar notoriedade no meio literário com a revista/ movimento Poesia 61, em que publica o texto "Morfismos". Fiama é considerada como uma das mais importantes escritoras do movimento que revolucionou a poesia nos anos de 1960. Este grupo rebela-se contra a palavra poética estereotipada, rasteira e discursiva. A revista-colectânea reflectia, por seu turno, uma tendência poética atenta à palavra, à linguagem na sua opacidade, na busca de uma expressão depurada e não discursiva.

E este grupo de jovens poetas, através da revolução da palavra poética, assumia uma posição mais profunda, de rejeição de um status quo cultural e político. Fiama participou nas revoltas estudantis do início dos anos 60 e deu cobertura, em sua casa, a jovens revolucionários que passariam à clandestinidade.

Em 1996 foi agraciada com o Grande Prémio de Poesia da Associação Portuguesa de Escritores e seu livro Cenas vivas foi distinguido em 2001 com o prémio literário do P.E.N. Clube Português. 
Confessa Fiama: "Comecei palavra a palavra [...] Assim: “Água significa ave'. A Poesia estava quase numa única imagem que coincidia quase com uma única palavra". 2

A palavra poética de Fiama, quer por via do cansaço perante palavras gastas e esvaziadas - cansaço partilhado pelo grupo de poetas da sua geração de juventude, Poesia $61^{3}$ - quer por via da própria aprendizagem múltipla da sua força de expressão, de procura, de "surto do real" (cf. Terra obscura) ${ }^{4}$ que nessa mesma palavra se reflecte, guia o leitorouvinte através de um universo complexo de correspondências, de quietude ou desassossego, de reconhecimentos ou de procuras. Essa mesma terra obscura tem presente a síntese paradoxal de Heráclito para a explicação do universo: o seu cerne, o seu centro, é o fogo e o verbo (lógos). Fiama entende, pois, a aprendizagem da palavra poética como a aprendizagem de um novo olhar sobre o mundo, em que os olhos e o espírito procuram o 'significado' da palavra-coisa numa chave de correspondências que conduz do múltiplo ao uno, por um contínuo esforço de olhar cultural, de síntese, sem barreiras à universalidade. Desse Uno floresce, como em árvore, uma infinidade ordenada de ramos que o poeta percorre em sentido contrário: é a Árvore da Vida, princípio activo da poesia.

Esse universo poético, que é o cosmos sob forma de textointerrogação, de motivo de espanto, de quietude reconhecedora de leis de permanência na mutabilidade, é habitado por imagens referenciadoras várias, de sentido complexo, como o mar, a praia, o pinhal, a casa, de paredes limitadoras e frias, para além da qual se estende a quinta, em cujo coração a árvore ganha especial valor - desde as raízes mergulhadas na terra à copa que exibe o fruto da sua seiva -, o campo, a cidade, na sua multiplicidade errática. Desse mesmo universo poético fazem parte as vozes referenciais da poesia, do teatro, da filosofia que constituem

${ }^{2}$ Cf. o texto "Fiama Hasse Pais Brandão (1938-2007): a fala do nome mágico". Disponível em: <https://www.publico.pt/culturaipsilon/jornal/fiama-hasse-paisbrandao-19382007--a-fala-do-nome-magico-117588>.

${ }^{3}$ Cf. SILVEIRA, 1986.

${ }^{4}$ BRANDÃO, 2006, p. 111. Esta é a edição utilizada e da qual, doravante, se citarão apenas as páginas. 
as matrizes do que somos, cultural e identitariamente, do que Fiama escutou, interiorizou, laborou em cotejos e sínteses, no seu percurso cultural, de Dante a Shakespeare ou a Goethe, a Rilke, a Homero, Heráclito, Platão, Plotino, Agostinho de Hipona, a Bernardim ou Camões, cujo universo poético tanto instigou Fiama e a levou a nele mergulhar hermeneuticamente com particular capacidade de leitura e sintonia, condensando essa sua compreensão de um discurso poético, ora claro, ora críptico, sob uma forma muito peculiar ao imaginário de ambos - a de labirinto. ${ }^{5} \mathrm{O}$ Camões elegíaco, que assimila, no seu neoplatonismo, a nostalgia hebraica do exílio, vertida nos salmos, empresta a voz a Fiama, por essa outra grande referência do seu universo cultural, que lhe corre nas veias, o Livro, como lhe chama, a Bíblia judaico-helénica e, creio, também a judaico-rabínica, que lhe teria progressivamente aberto as portas ao fascínio pela procura cabalística do entendimento das equivalências num universo animado pela Árvore da Vida, seu segredo, raiz e fim.

A diversificada formação cultural de Fiama, o multiculturalismo que em si assume e lhe corre no sangue constituem a razão mais forte para que esta procura poética, que é procura da vida e do seu sentido mais profundo, seja imbricada, labiríntica, propícia à recolha reflexiva em si mesma ou no útero-caverna das palavras e do pensamento antiquíssimo, como recolha iniciática. Assim, perseguir na sua obra poética marcas do universo greco-latino leva-nos, inevitavelmente, à verificação de que raras vezes elas se encontram isoladas, autónomas, alheias a associações outras. Elas põem lado a lado contemporaneidade e Mundo Antigo, geografias diversas, como $O$ Xanto, o Tibre e o Reno,${ }^{6}$ poesia alemã e poesia grega, universo bíblico e universo helénico ou romano. Ou então, identifica-se o tópos clássico, liberto de referências.

Assim ocorre com o famoso símile das folhas de árvore da Ilíada, VI, 146-149: ${ }^{7}$

\footnotetext{
${ }^{5}$ Viria a reunir num volume, publicado em primeira edição de 1985, os seus estudos sobre Camões e outros autores da Literatura Portuguesa em O labirinto camoniano e outros labirintos: temas de Literatura e de História Portuguesas, 2007.

${ }^{6}$ Que o mesmo é dizer: a ancestral Troia homérica, Roma, com todas as suas memórias, e a cultura gótico-germânica. Poema pertencente ao ciclo "Dizer Avis”, p. 113.

${ }^{7}$ A tradução da Ilíada é de Frederico Lourenço.
} 
Assim como a linhagem das folhas, assim é a dos homens.

Às folhas, atira-as o vento ao chão; mas a floresta, no seu viço

Faz nascer outras, quando sobrevem a estação da primavera:

Assim nasce uma geração de homens e outra deixa de existir.

Fiama oferece-nos uma "Folha viva" (p. 93, do ciclo "Pungente o verde"), eco da folhagem homérica mas mais ampla, abrangendo o todo do que vive, perece e se renova, nos segredos de uma convergência de que só a Árvore da Vida é ícone e suporte verdadeiro:
Mantém-se o ramo vivo
da verdura. A folha
cai, repõe-se, a copa reverdece,
o seu volume sobe.
Nada é efémero
Sob o tom da luz. Tudo
Retoma a folha, tem recorte,
O seu pecíolo verde ou outra forma.
Cai a folhagem, tinge todo o chão,
Ou possuída a terra, ela persiste
E é perene a queda
De uma árvore; depois o surto,
E tudo convergente, se mantém.

A profusão de tópicos, referências diversificadas leva-me, tendo em conta o âmbito deste artigo, a seleccionar as referências mais expressivas e frequentes, com a preocupação de evitar a dispersão no discurso ou a mera catalogação de tópicos. Proponho-me proceder, então, a um percurso interpretativo, no intento de os compreender no seu contexto e na sua interrelação, tendo em conta o contexto mais lato do próprio universo poético de Fiama, na sua riqueza e complexidade. Selecciono três vectores da vivência e do imaginário poético de Fiama, conglutinadores da sua proximidade ao mito e do seu labor poético de síntese: o caminho da vida, errático ou de procura e encontro (de matriz também bíblica) e que abre espaço ao motivo do labirinto; ${ }^{8} \mathrm{a}$

\footnotetext{
${ }^{8}$ Sobre a pluridimensionalidade e a plurissignificação do caminho na Cabala, veja-se: FORTUNE, 2010, p. 23 ss.
} 
correspondência de mundos e símbolos e a ascese através deles, da mutabilidade aparente à permanência, o que envolve, particularmente, a presença de referências à filosofia grega, entrelaçadas, frequentemente, com elementos esotéricos, em particular de cariz cabalístico (exílio, separação da Árvore da Vida e nova reunião redentora de Deus e da sua Schekina ${ }^{9}$ ); a vida que anima a palavra - a palavra poética, que é também música, na sua harmonia, e que se torna imperativo para escutar os ecos harmónicos de um universo primordial e coeso (Orfeu, Anfíon, Homero e os heróis e deuses cantados na saga homérica).

A palavra viva, aquela que radica e ecoa desde antes de a poesia ou filosofia se aprisionarem na escrita, anima o imaginário de Fiama - palavra anunciadora, como os vários anjos, palavra-caminho, que instiga ao percurso do labirinto da interrogação, escutando os sinais, cruzando-os, sendo seu intérprete, como os antigos magos. A cidade, por exemplo, toma a forma de labirinto pétreo, não urbanizado, porque desumanizado ("Jazente", p. 143) e "o grande Minotauro hoje chama-se Chernobyl” ("O bucolismo deixará de ser um canto", p. 633), já que os monstros do passado, "da nossa antiga pátria, a Grécia”, podem ameaçar o presente. Não estamos, pois, perante alguém que celebra um passado utópico na poesia. Por vezes o sentido de um poema completa-se com o do subsequente, como é o caso da relação entre o poema que acabei de referir e o que leva o título de reminiscência bucólica "Sed in Arcadia", ${ }^{10}$ p. 635) do mesmo ciclo "Cenas vivas".

Na cidade aprendeu Fiama "o sentido da inocência" como consciência reminiscente da sua vida passada: "e então amei o lugarcomum rural da minha vida, escrita depois dos bíblicos pastores de Hebron e dos idílios da Idade Clássica" ("Canto da inocência”, p. 583), do ciclo "Cantos do canto".

\footnotetext{
${ }^{9}$ SCHOLEM, 2003, p. 157-169.

${ }^{10}$ Expressão cunhada em Virgílio que aparece, sob a forma et in Arcadia, na pintura seiscentista italiana (Guercino, 1618, quadro assim legendado, em que dois pastores fixam os seus olhos num crânio, como se a existência na Arcádia, sinónimo de vida feliz, tivesse, mesmo assim, como limite a ter em conta, a morte) e em Poussin (1637). O tema é retomado por Rezende.
} 
O labirinto visível está na Terra, materializado, e tem voz através do mito de Teseu e Ariadne ("Canto do labirinto", p. 581), "no entanto, no imo do espaço, o outro labirinto espera-me em cada dia de perda e salvação", um Labirinto imóvel, alcançado pela meditação como olhar interior, de ascese à forma. Ao labirinto material se associam as figuras de Dédalo e Ícaro, em outros dois poemas, ou ele converte-se na própria errância que encontra corpo em outro mito, o das viagens de Ulisses, para o qual Ítaca representa, simultaneamente, mutação e permanência: "tudo passa e regressa. Somente o servo se apagou como vela antes das gerações vindouras" ("O Servo", p. 663).

Este labirinto, a caminho do meio iniciático (caverna, ou $\operatorname{mar}^{11}$ ), é também o do percurso do eu lírico de Fiama, a caminho da praia, como um outro Ulisses, ligado ao mar dos seus rumos de error e encontro: é esse o pressuposto do poema "Caríbdis" (p. 492).

O outro tipo de permanência, associada a Ítaca, a de Penélope, dobrada sobre a teia de si mesma, que a isola do mundo e a imbrica num tecido infindável, é rejeitado por Fiama ("Sunt lacrimae rerum", p. 479). Uma vez amada por Ulisses, Penélope desprende-se do mundo, para se deixar prender na teia - e esta prisão na teia antecipa a Mãe ausente, na sua infindável renda, em Sob o olhar de Medeia. A teia de Penélope (em que se adivinha o mito de Aracne), diversamente do labirinto de Ulisses, constitui um labirinto sem saída, como o ilustra o poema "Tecelagem" (p. 182). Apenas o Amor, no regresso de 'alguém' que penetra os muros da cidade, a resgata da queda e do fim:

No dia em que regressou à ilha de Ítaca o sol tudo se mudara, embora a tecelagem deliberadamente simbólica fosse, por exagero, interminável. Na verdade não só isso mas tudo tendia a ser outro. Havia chovido brandamente na véspera entre proas. $\mathrm{O}$ raio brusco repentino intenso colorira de novo tom muralhas. Supunha que na cidade alguém ainda entrara como cidadão e recebera todo o direito

\footnotetext{
${ }^{11} \mathrm{O}$ mar, na sua infinitude, é, simbolicamente - e é-o na poesia de Fiama - espaço de morte mas também, e simultaneamente, espaço baptismal de renascimento e purificação. Sobre o mar na poesia de Fiama, vide Fialho (2006).
} 
da cidadania. Dando à população a figura, habituando-nos ao desconhecido. Hoje, ela esplende ao tear. Ontem nem a tecelã, ninguém e nada haviam podido furtar-se ao início do fim.

Será, de algum modo, essa a resposta procurada - a do Amor, de elos cósmicos e humano - pelo olhar inquiridor e demiúrgico de Medeia, em Sob o olhar de Medeia, ${ }^{12}$ no seu percurso labiríntico pelo mundo, destacado do de um possível Jasão, invisível, incorpóreo e simbólico, movido pela mágica ambição de encontrar o Velo de Ouro.

Todavia, o ritual e do trabalho da lã, "tela viva", a partir da tosquia até à "arte antiga de fiar", inscreve-se nessa cadeia de memória milenar de ritual dos gestos, cíclico, repetitivo, mas ligado à vida, numa espécie de recuperação do sentido dos gestos das gerações passadas, desde os pastores bíblicos à infância de Fiama ("O Meu gado”, p. 490), como se tal ajudasse a ultrapassar o sentimento do exílio - sentimento e situação bíblica do povo de Israel, longe da Jerusalém-plenitude, mas sentimento que também aproxima Fiama do grande exilado da poesia romana: Ovídio, o "O sulmonense Ovídio, exilado" cantado também, em elegia, por outro exilado genial, tão caro a Fiama: Camões ("Memorando, estando no Delta do Danúbio”, p. 600).

Percurso mais rico que o de Penélope é o da conversão de Nausícaa, propiciado espiritualmente pelo meio iniciático "mar". Nausícaa converte-se, pela presença de Ulisses, o estímulo do amor, e pela voz do poeta (Homero) simultaneamente, em Amador e Amado, tal como o "eu lírico" de Fiama em "O Canto de Nausícaa” (p. 582):

Cada Poeta amou o meu ouvido, e hoje, ao som do mar, dou-lhes a boca da Amada à espera da metamorfose:

"Foi o mar que me fez criança, em jogos de praia, de bolas, de arcos, rítmicos, e quem me chamou Nausícaa foi o Poeta.

\footnotetext{
${ }^{12}$ Sobre a demiurgia poética de Fiama, buscando, pela palavra, caminhar num universo onde seja possível desvelar as equivalências ao nomear as coisas, veja-se Sousa (2001), p. 34.
} 
Se eu não fosse Nausícaa mas o arco tudo seria igual, porque a acção do amor sobre a coisa amada, estando na mão

de Nausícaa ou no ar, seria a mesma de transformar no todo as duas partes."

Ela e o arco ou eu e o Poeta, quando deixo de ser poeta e sou a Amada que age sobre as coisas transformando-as.

É aqui evidente, além do mais, a presença da influência camoniana ("Transforma-se o amador na cousa amada").

Se o caminho e os errores de Ulisses decalcam o modelo do labirinto, na saudade da casa e na procura do reencontro com ela e consigo mesmo, uma outra procura, desta decorrente mas com coloração contemporânea, historicamente vinculada à própria biografia política de Fiama nos tempos da ditadura, é projectada sobre o perfil do herói: a da afirmação de uma cidadania libertadora, ainda que tal gesto passe por ocultar-se para se revelar: cavalo de Troia ou gruta de Polifemo, esotericamente correspondentes à caverna-útero iniciáticos a partir de onde o renascimento é possível, ainda que o risco da morte e do desconhecido estejam presentes, prestam-se a essa gestação de um mundo novo, que não é novo, afinal, mas que representa a reposição da justa ordem. Atesta-o o poema "Ulisses, outro" (p. 202): ${ }^{13}$

Com o cavalo de madeira recuperar

a cidadania, a distinção

entre a carne e a construção, o desconhecido.

O tempo é uma ilusão, quando se buscam ou tocam os segredos da eternidade, da permanência para além do mutável. Assim, no poema "Casa ou um vale" (p. 54, de "Nome lírico") se canta a mesmidade

\footnotetext{
${ }^{13} \mathrm{O}$ referente histórico deste poema - e, logo, o sentido possível deste - ganhou para mim luz ao escutar o depoimento de Gastão Cruz sobre a biografia de Fiama e a sua luta política comum, de juventude, ao acolherem, com risco, na clandestinidade da noite, activistas políticos perseguidos, em sua casa.
} 
circular que tem o solo como meio de representação, equivalente ao rio. O solo, a terra, em que o homem está radicado, constitui, além do mais, também, heideggerianamente, a sua casa, a partir da qual faz a sua experiência de mundo e de pertença, de 'Befindlichkeit':

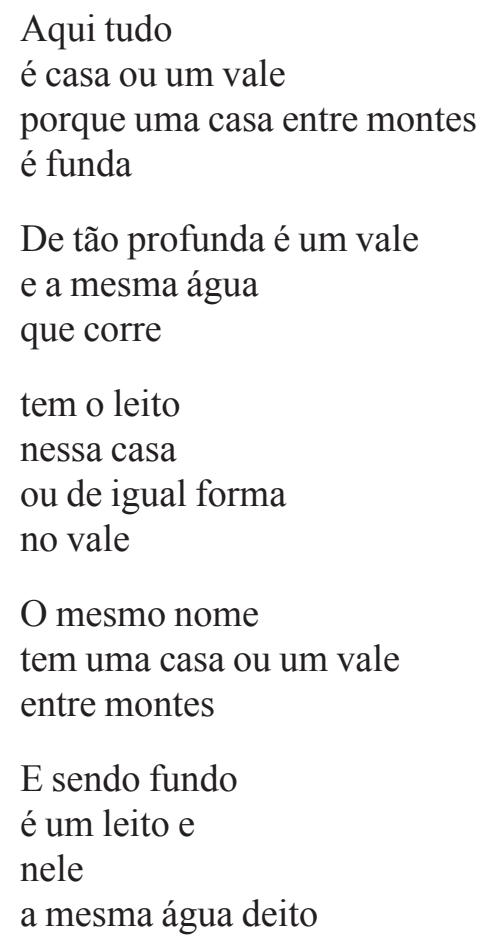

Ao líquido meio que flui e que Heráclito vê como imagem da eterna mudança, contrapõe Fiama a hera no muro, como sendo ela mesma a "Hera de Heráclito", num jogo de palavras - da planta e do nome próprio - que é o de sentido do cosmos: “[...] pensarei/ as palavras de um pensamento em corpo/preso ao fluxo e à rede das raízes/(radículas) contra o muro" (p. 11-112, do ciclo "Germinações"). Gea, do poema do mesmo nome ("A Gea”, p. 107), constitui essa milenar e mítica entidade da permanência e, logo, da espera, ou esperança, que envolve o devir como acidente, mas, ainda assim, com a morte implícita: 
Gea, mãe terrena. Poisar sobre as (minhas)

espáduas uma palavra: espádua.

Hoje, parágrafo vão, meio-dia sem tempo; mas, no lugar,

pobre permanência,

esperar ou (o) vir.

Das “espáduas esquecidas do corpo de Gea" falará no "Poema 14" do ciclo "Rosas" (p. 295). Gea, mãe de deuses, na mitologia grega, parece fundir-se aqui com o princípio do feminino (Binah, a terceira Sephirah), separado transitoriamente do do masculino (Chokmah, a segunda Sephirah), ${ }^{14}$ no Deus da Cabala, e na projecção na Árvore da Vida - feminino que é útero, força de nascimento e, por isso, princípio de vida mas também de morte, nessa vida finita, só recuperável para a imortalidade na re-união de princípios.

O poeta Hesíodo, cantor do mito das idades, é celebrado por Fiama como o cantor da circularidade.

O segredo do âmago dessa permanência na essência oculta do que é e se corresponde constitui a chave da presença recorrente do universo e da figura de Platão e Sócrates na poesia de Fiama. Para além do Livro, a Bíblia, naturalmente, a obra em dez livros, de Platão, A República, certamente, condensam o mistério, assumem a ligação de mundos, no mito de Er, objecto de outro poema (p. 410, do ciclo "Âmago I. Nova Arte"), ou, de acordo com a fórmula "tudo o que está em baixo é igual ao Alto" 15 a escada de Jacob (Gen. 28. 11-19) e a anamnese platónica são animadas do mesmo movimento ascensional do espírito, para a primeira se destacar, apontando para a ciclicidade no fluir do tempo e, à luz da interpretação cabalística, para a correspondência entre a parte superior do ciclo e a inferior, para a capacidade ascensional daquele que é tocado pela manifestação, do alto para baixo, de Javeh. Centremo-nos no poema $E r$, que leva o nome da personagem do conhecido mito do homem que, após ter vivido a experiência de morte e de permanência da sua alma no Além, regressou à vida, lembrado do que tinha contemplado da grandiosa perspectiva de mundo espiritual que visitara, mito contado no final do Livro X da República:

\footnotetext{
${ }^{14}$ FORTUNE, 2010, p. 104 ss.

${ }^{15}$ Canto da ave e do sótão, p. 571.
} 
Por fora do coração voa a asa negra do melro. O mesmo que vive na minha vida. $\mathrm{O}$ que tem um assobio tranquilo e eterno.

Segue-me com o seu amor ocul to. Une o o olhar do solo raso ao olhar sobre a altura. Muda e depois é igual. Por vezes ve mo-nos nas brenhas junto ao mar.

Noutro tempo foi numa aresta verde.

Vem da viagem de Ulisses. Um cantor. Nas figueiras de Ogygia cantando. Sobre um fio de er va. Oiço-o com a mesma penetra ção com que já foi ouvido na Natureza. Por Er. Além os pequenos pardais negam-no. Não os contemplo. Todos os anos estou atenta. Este poema afirma e recorda. Esta ave chama por mim como eu.

Pássaro e poeta identificam-se, como se um fosse a alma da outra, ou o espelho da sua alma. O chamamento desperta a reminiscência e segui-la significa entrar na consonância do ritmo e dos segredos da Natureza, rítmica e eterna. Pássaro de contradições, negro mas de canto suave, leva a cor da morte e a marca da eternidade. Une espaços e tempos: o solo às alturas, o feminino, porventura ao masculino do Alto. Dinâmica de anseio por união do que está separado, o melro-Er tem o movimento da alma. A sua 'viagem', assinale-se, é similar à de Ulisses. Cruzam-se, assim, os polos mitológicos acima indicados, sob o signo do exotérico. Tudo é correspondência. Ulisses é Er, nessa viagem iniciática em busca de si mesmo e da perenidade serena. O labirinto daquele será transcendido quando o grande Mistério se lhe revelar. Morte e renascimento encontram, na reminiscência que "Estas Acácias, Outras" (p. 127, do ciclo "Solo Solo") despertam, a partir da árvore desgastada pelo verão, perante os 
olhos da poeta, para a simbólica acácia ligada ao mito da morte, sepultura e redenção do Mestre Construtor Hiram, mencionado no Livro dos reis 1. 7-13. O mito, que não consta da Bíblia (apenas o nome e a função da personagem), associa ao sinal para reconhecer o túmulo do Mestre, assassinado pelos maus discípulos, um ramo de acácia, a árvore sempre verde e, por isso, tornada símbolo da imortalidade. ${ }^{16}$

O Fedro constitui, porventura, para Fiama, o mais amado dos diálogos platónicos, espelho da voz de Sócrates, não presa à escrita ("Ninguém tanto quanto Sócrates", p. 641). Com o mesmo Sócrates que interpela Hípias - "Como se explica, Hípias, que os antigos sábios/ todos se tenham afastado dos negócios públicos?” (p. 612, do ciclo "Elegíacos") se identifica Fiama, assumindo como sua, na primeira pessoa, a pergunta feita em Hipias Maior. A pergunta de Sócrates é a de Fiama, porque toca Fiama no seu itinerário de vida: eu lírico e poeta empírico tocam-se, mediados pelo mundo antigo da filosofia e da poesia: "Ainda amo, neste exílio de paz, a mesma Paz// Sábia não sou. Caleime porque/as memórias minhas e a voz sozinha/ também pertencem ao Todo, em harmonia". O sábio é livre, como o poeta, o sábio é o sacerdote do mistério da humanidade e da vida: "e a memória retém o objecto e o outro, tronco de choupo ou copa de limoeiro; conhecermo-nos como diz Sócrates, é conhecermos no Outro quem nós somos" ("Canto da sombra", p. 561). Princípio de vida, proximidade entre os homens, decorrente desse mesmo exílio que é afastamento do cosmos das ideias, mas biblicamente vertido, o conhecimento de si mesmo, gravado como imperativo no templo de Delfos, decorre da reflexão e do silêncio que busca unir o que aparentemente é disperso. É óbvia a síntese de universos culturais aqui alcançada, sob o signo da Grécia.

Cruzam-se também os dois núcleos temáticos já referidos com o terceiro, o do poder da palavra-melodia poética primordial, antes da sua fixação ao escrito. Heitor, o mito de Tétis e Aquiles, o herói da Ilíada tornado 'quase imortal' pelo banho dado pela sua mãe divina que, ao segurá-lo pelo calcanhar, deixou de fora da água da imortalidade essa ínfima parcela corporal do filho, condensa a nossa quase-imortalidade (“A Thetis", p. 471):

${ }^{16}$ PEREIRA, 2008, p. 14. Também as Tábuas da Lei foram encerradas numa arca de ouro, fechada numa de madeira de acácia (Exodo, 37.1-4). Cf. MOORE, 2009. 
O pinhal, no atalho para a praia.

Pude compará-lo mais tarde a Proteu.

Um só pinheiro, que hoje posso situar

também no Oriente. O que me permitiu

modelar um pequeníssimo utensílio.

Rolas de Junho, veterotestamentárias, tam-

bém, e mestras de seu nome. O regresso,

quando as pinhas, excêntricas em relação

à massa verde, se confundiam nos meus vo-

cábulos com pássaros crocitantes. $\mathrm{O}$

pinhal, iniciador de sons vegetais.

Antecãmara do mar. Êxtase anterior.

E a água sapiencial. A do mar, que

se transformava em sabedoria.

(Veja-se a gravura de Thetis que banha

Aquiles na taça de mármore das abluções.)

O poder dessa voz primordial, que toca os homens, que move mundos, que abre o espírito, habita em Homero, em Euclides, como referência antecipada do que é 'geo-metria', na voz profética de Isaías, Empédocles ou na elevação que habita o cântico dos filhos destes - o gregoriano ("Isaías, Empédocles, filhos", p. 159). Assim, Orfeu, poeta mágico, ou Anfíon, têm o seu lugar na escrita poética de Fiama, ainda que Orfeu represente, mais que Anfíon, o cantor que move as pedras e constrói a muralha de Tebas (“Anfíon”, p. 138), o cantor mágico mas marcado pela ausência: Eurídice (cf, "Canto de Orfeu”, p. 587 de "Cantos do canto"). Orfeu suspende a sua lira e é destruído por não lograr o tão ansiado papel de mediador de mundos, de Hermes Trimegisto (cf. "Hermes Trimegisto", p. 281), equiparado a Eros, mediador de mundos no contexto platónico (cf. "As rãs de Hermes", p. 478-479), ou correlato da mors, no jogo vocabular latino amor-mors.

Os vários anjos de Fiama - ángeloi, mensageiros ${ }^{17}$ - representam, igualmente, tentativas frustradas dessa ligação conseguida, ainda que deixem dela sinais.

${ }^{17}$ Sobre o significado cabalístico dos anjos, a que não são alheios os vários anjos de Fiama, veja-se Fortune (2010), p. 100 ss e p. 240 ss. 
Mensageiros serão, de uma sabedoria antiga, os:

livros belos que ardem e ressuscitam

Com a força das próprias árvores vivas,

Como aquelas dos hortos de Alexandria

De onde nasceram os textos

Que, entre o pergaminho e o papel,

Guardaram para a Europa as mãos magníficas

Dos árabes e dos Gregos mortos.

No tardio Ocidente imaginámo-nos

A ler as páginas surdamente s'so, Como se fossem escritas pelas línguas

No interior da nossa boca omnívora.

A pouco e pouco os livros penetraram

No interior da fronte, nos olhos

E a mão afeiçoou a página

Como a plaino afeiçoa a madeira. ${ }^{18}$

O regresso e a saudade do som da palavra viva, da palavra que é ouvido, como Homero, para escutar o grande texto do mundo, na magna caminhada em que os segredos - o Segredo - se oferecem renovadamente a desvendar, sempre insondáveis, moveram já civilizações e poetas, moveram profetas e sacerdotes, animados por essa força única que é o Amor, Amor Eros universal, configurado em todos os mitos de amor, ainda que mesmo no reino vegetal: a luxúria das glicínias, lúbricas de luz e a ela entrelaçadas, pagam o preço do amor ao sol, como uma hýbris de tragédia grega ("Da übris", p. 722), mas o facto de secarem "sempre no Outono" implica que de novo renasçam, na Primavera, no mesmo eterno ciclo que tudo move e perpetua. A palavra poética que nomeia e cria mundos reside no eco homérico, "a primeira fase épica da memória", "os cérebros dos aedos" que, ao disseminarem a epopeia e a memória dos seus heróis, a verteram para línguas estranhas, mas deixaram viva a saudade "da origem/da expressão silenciosa contemplativa" ("Se eu estiver a discorrer sobre a loucura", p. 219-220).

Em outro poema ("Teoria da realidade, tratando-a por tu", p. 699-700) Fiama convida:

${ }^{18}$ De "Canto da perda dos livros", p. 573. 
Falemos mais dos gregos, que amaram o mar com a boca do canto dos aedos e da escrita, e com os barcos, que apontavam pelas linhas dos códices, na singradura.

Ó realidade homérica, tu és pelos tempos traída, pelas línguas, e eu, que medeei da fala para a leitura, eu leio as epopeias para ti.

Se foste tu, digo-te, a primeira após a fala, e a palavra do poeta seguida pelos poetas, seguidora de todos, quero louvar-te a ti. Sabes o que é o canto, tu? A medida contada? A harmonia flui do meu ouvido, o falado pela ordem das sílabas, as pausas, as vogais entoadas. Som, palavra dada, do abstracto ao tacto do meu ouvido. Manhã, infância em que a mãe de luz embala as palavras no canto.

Como sacerdotisa vigilante de Afrodite se assume Fiama sacerdotisa apaixonada do amor - capaz, por ele, de arrostar a morte, consoante o mito de Hero e Leandro, ${ }^{19}$ que consagra num dos seus poemas ("Poética de um rosto", p. 476).

Purificando-se pelo mar de morte e redenção baptismal, pelo fogo, que é consumpção de amor e morte, até à hesychía, a helénica paz contemplativa da experiência da presença e da posse do divino, que

\footnotetext{
${ }^{19}$ Este mito trágico de amor inspirou poetas antigos, como Virgílio (Georg. 3. 258 e seguintes) ou Ovídio (Her., 18 e 19), mas também poetas posteriores, como Byron ou o nosso Bocage. Hero, a virgem sacerdotisa de Afrodite em Sesto, e o jovem Leandro, de Abidos, apaixonaram-se. A fim de se encontrarem, Leandro atravessava de noite, a nado, o Helesponto, guiado pela lucerna que a amada lhe acendia na outra margem. Certa noite de tempestade, a chama extinguiu-se e Leandro encontrou a morte nas águas revoltas, em plenas trevas. Ao clarear o dia, Hero, vendo o corpo do seu amado à mercê das águas, atira-se do alto para o mar, pois não suportou sobreviver à morte do amado.
} 
dá o título a dois poemas (p. 534), o eu lírico de Fiama aproxima-se da experiência do Coro das Bacantes, em Bacantes de Eurípides ${ }^{20}$, ao cantar essa paz suprema a que também dá voz - voz imortal e serena, no banquete sagrado de Dioniso (Bacantes, v. 383), sublinhada pelo silêncio que está para além das palavras, aprontando o sereno banquete final no grande crepúsculo que confina, uma vez mais e sempre, ciclicamente, com as auroras a que Homero emprestou dedos róseos: festim do início, festim final, na mesa posta que se oferece em emoções contidas, entre a palavra e o silêncio. "O mestre anunciado ausente" de "Hesychia 1" preenche toda a espera e abre, no silêncio, essa possibilidade serena de "estender-se o braço até ao fundo/ da longa mesa posta para as coisas" ("Hesychia 2").

O banquete é o tempo da reunião e convergência, da oferta do que se dá a conhecer, conjugado com a sede da procura e da espera do Amado bíblico que já se anuncia. Banquete poético e cultural, em que o Mundo Antigo se entretece com outras luzes, como a Hera de Heráclito, num percurso de iluminação encontrada e procurada: banquete em que Dioniso e eros inspiram os convivas do Sócrates platónico (e a hera de Heráclito é a hera de Dioniso), banquete em que a alma espera ser saciada com a presença do seu Senhor, numa Jerusalém que fica para além do exílio e que os rios camonianos e veterotestamentários anunciam.

\section{Referências}

BRANDÃO, F. H. P. O labirinto camoniano e outros labirintos: temas de literatura e de história portuguesas. Lisboa: Teorema, 2007.

BRANDÃO, F. H. P. Obra breve: poesia reunida. Lisboa: Assírio e Alvim, 2006.

BRANDÃO, F. H. P. Sob o olhar de Medeia. Lisboa: Relógio d'Água, 1998.

EURÍPIDES. As bacantes. Trad. Maria Helena da Rocha Pereira. Lisboa: Edições 70, 1992.

FIALHO, M. C. O mar na poesia portuguesa contemporânea: a escrita de Fiama Hasse Pais Brandão. In: OLIVEIRA, F.; THIERCY, P.; VILAÇA, R. (Coords.). Mar greco-romano. Coimbra: Imprensa da Universidade, 2006. p. 397-415. DOI: https://doi.org/10.14195/978-989-26-0438-1_21.

${ }^{20}$ EURÍPIDES, Bacantes, v. 389. 
FIAMA Hasse Pais Brandão (1938-2007): a fala do nome mágico. Público, Lisboa, 21 jan. 2007. Caderno Cultura Ípsilon. Disponível em: $<$ https://www.publico.pt/culturaipsilon/jornal/fiama-hasse-pais-brandao19382007--a-fala-do-nome-magico-117588>. Acesso em: 21 jan. 2007. FORTUNE, D. A cabala mística. Tradução de Mário Muniz Ferreira. São Paulo: Pensamento, 2010.

HOMERO. Ilíada. Tradução de Frederico Lourenço. Lisboa: Cotovia, 2005.

MOORE, D. A Guide to Masonic Symbolism. Hersham: Ian Allan Publishing, 2009.

PEREIRA, P. M. Dicionário de termos maçónicos. Lisboa: Produções Editoriais, 2008.

SCHOLEM, G. La Kabbale et sa symbolique: Jean Boesse. Paris: Payot, 2003.

SILVEIRA, J. F. da. Portugal: maio de Poesia 61. Lisboa: IN/CM, 1986.

SOUSA, C. M. de. Na sabedoria de uma quietude: Três rostos de Fiama. Relâmpago: revista de poeesia, [s.1.], n. 8, p. 27-43, abr. 2001. 